\title{
研削屑を利用した再生超硬合金の機械的性質
}

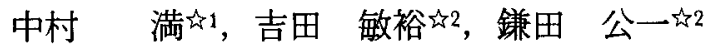

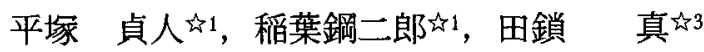

41 岩手大学工学部, $\mathbf{T} 020$ 盛岡市上田4-3-5.

如岩手県工業技術センター, 宁020 盛岡市飯岡新田3-35-2.

象3 東北和田工業物), 勇028-13 岩手県下閉伊郡山田町石峠3-17-4.

\section{Mechanical Properties of the Recycled Hard Metals Utilized by the Grinded Wastes}

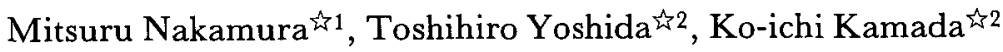 \\ Sadato Hiratsuka ${ }^{\text {औ1 }}$, Kohjiro Inaba ${ }^{\text {in } 1}$ and Makoto Takusari 3 \\ tr1 Fac. Eng., Iwate University, 4-3-5 Ueda, Morioka 020. \\ 42 Industrial Research Institute of Iwate Pref., 3-35-2 Iiokashinden, Morioka 020. \\ \&3 Tohoku WADA Ltd., 3-17-4 Ishitouge Yamada Shimoheii-gun, Iwate 028-13.
}

Received January 17, 1994

\begin{abstract}
WC-Co type hard metals using for the die materials are mainly machined by grinding. The grinded wastes produced by grinding, which are very fine grains $(<10 \mu \mathrm{m})$ were thrown into the discard at present. In this experiment, the recycling technique of grinded wastes were studied. The mechanical properties of recycled metals were examined by hardness test $\left(H_{R} A\right)$ and the transverse rupture strength test.

As a result, it was found out that the recycling process of the grinded wastes could be completed by 7 processes. Especially, the reducing process at $1073 \mathrm{~K}$ and the recarburizing process before the compacting process were very important. The recarburizing process was to add graphite of total 6.0 mass\% . The mechanical properties of recycled metals were almost satisfied with JIS standard values (H5501).
\end{abstract}

\section{1 緒 霅}

代表的な工具材料である超硬合金は，組成により WC-Co系とWC-TiC-TaC-Co系に大别されるが，いずれ の組成においても，WやCo等の希少資源を主成分にし ている.また，その製造や加工が篗しいため高洒な ものとなっているので使用済みの工具類は回収され 各種原材料として再利用されているが1-3), 金型, 工 具加工メ一カーで超硬合金の研削加工で生じた多量 の研削屏は回収されず、業者に委託し有料にて廃棄 しているのが現状である.しかし，この超硬合金の
研削屏は研削時の切込量が, 数 $\mu$ 䀦程度と小さいため 微扮末状椇であり，粉末冶金の原料粉末として再利 用できる可能性がある.

本研究はこの研削屑の再利用による超硬合金の再 生加工技術について㭲討した。実験では可能な限り

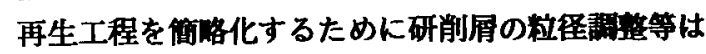
行なわず，還元および加炭等の成分調整を試み，よ り経済的な方法による再生技街について検討した。

再生した超硬合金はその物性值，特に抗折力に及 ほす䣷素, 炭素等の影䉕について検討した。 


\section{2 実 験 方 法}

本研究で用いた研削首はJIS規格 (H5501)でG種3号 に分類される超硬合金（WC-Co）の平面研削盤による 研削屑であり，研削条件は超硬合金製の金型研削条 件としては一般的に行なわれている粗研削時での切 込量0.5 1mm，仕上げ研削時での切込量2 $5 \mu \mathrm{m}$ とし 特に歓粉末を得るための条件は与えていない研削首 を用いた。

Fig.1に本実験のフローチャートを示す.回収した 研削屏には，水分，油分および研石（合成ダイヤモ ンドーレジンボンド）からの不純物が混入している ためアルコールまたはアセトン洗浄に加え蒸留水で 数回擳汼洗浄し，真空乾燥後 $100 \mathrm{mesh}(-150 \mu \mathrm{m})$ の心 るい分けを行い，粗大な異物および疑集体を除去し た. 実娩では

1 : 洗浄，乾燥処理した研削屏をそのまま用いた もの（研削首と呼ぶ）

2:1の研削屏を水素雾囲気炉で邊元処理したも の（還元屑と呼ぶ）

3:2 の還元処理後にさらに黒鉛添加による加炭 処理を行なったもの（加炭首と呼ぶ）

の3種類に分け，それぞれ成形十焼結加工後各種の 試験を行なった。

物性評価としては压粉復度および䌇結密度湘定，

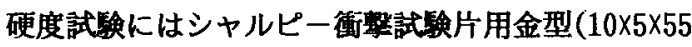
mm)に槙結した試験片を用い,ロックウエルAスケー ル $\left(\mathrm{H}_{\mathrm{R}} \mathrm{A}\right)$ で評価した．抗折試娩片形状も同様で、支

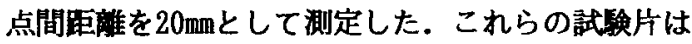
表面の凹凸を一定にするためダイアモンド砥石を用 い 4 面を平滑 $(<1.0 \mu \mathrm{m})$ に研削した.

なお，本研究は工業製品の廃棄屑を利用したリサ

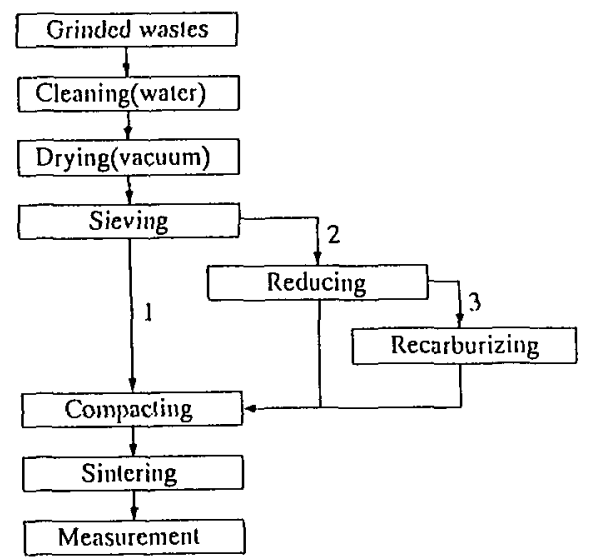

Fig. 1 Experimental procedures of recycling process on this study.
Table 1 Chemical compositions and particle size distributions of grinded wastes obtained.

\begin{tabular}{|l|c|c|c|c|}
\hline \multirow{2}{*}{ Material } & \multicolumn{4}{|c|}{ Chemical composition (mass \%) } \\
\cline { 2 - 5 } & W & Co & C & Fe \\
\hline Grinded wastes & bal & 8.7 & $4.5 \sim 5$ & 0.14 \\
\hline \hline Sintercel compact (JIS G3) & $83-88$ & $7-10$ & $4 \sim 6$ & - \\
\hline
\end{tabular}

\begin{tabular}{|c|c|c|c|c|c|}
\hline \multicolumn{5}{|c|}{ Particle sizc distriluution $[\mu \mathrm{m}]$} & (mass\%) \\
\hline-1 & +1 & +5 & +10 & +20 & +44 \\
\hline 11.37 & 26.78 & 24.00 & 12.19 & 13.30 & 12.36 \\
\hline
\end{tabular}

イクルを目的としているので，再生超硬合金の物性 值の比較としてJIS規格(H5501)を参照した.

\section{3 実 験 蛣 果}

Table 1 に平面研削加工によって得られた研削屏 の化学組成と粒度分布を示す. 市販焼結品JIS（G3） と比較すると，ほほ同様の組成を示すがC量が若干 低い。これは研削加工により脱炭が起きていること が予想された. また, Feの存在も確諗され研削盤等 の材料からの混入と考えられた.

研削屏の粓度分布は $1 \mu \mathrm{m}$ 以下から $44 \mu \mathrm{m}$ 以上まで かなりのばらつきが見られたが，これは粗研削の影 響であると考えられた.市販超硬合金粉末が $10 \mu \mathrm{m}$ 以 下であることを考えると $10 \mu$ 员上上の屏を粎 $38 \%$ 含 む結果となっており，この比较的粗大屑が再生合金 の物性値に与える影響についても検討した。

Fig. 2は成形圧力と王粉密度の関係を示している. 研削莌のままの成形では圧粉密度で $4 \sim 5 \mathrm{Mg} / \mathrm{m}^{3}$ とな り市販粉からの成形 ${ }^{4)}$ に比べて約 $50 \%$ と著しく低下 し成形が困難なケースもあった。これは粒径のばら

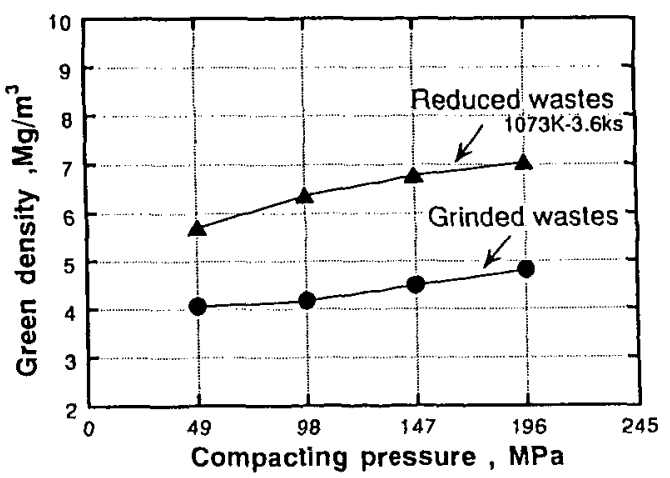

Fig. 2 Relation between the compacting pressure and the green density of 2 type wastes. 


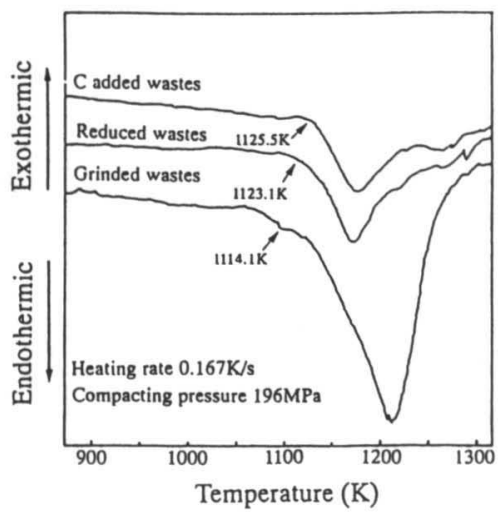

Fig. 3 Results of differential thermal analysis of 3 type treated wastes.

つきによる成形圧力分布の不均一さや屑の酸化等に よる粉体流動性の低下が原因として考えられる ${ }^{5)}$.

そこで, 研削屑中の酸化物等を還元するため, 水 素雾囲気妒を用い1073K-3.6Ksの条件で還元処理を した結果, 圧粉密度が研削首のままのものに比べて 約1. 5倍 $\left(6 \sim 7 \mathrm{Mg} / \mathrm{m}^{3}\right)$ まで向上した.この還元処理温 度は1073〜1173Kの範囲で各々3. 6Ks保持の条件で行 なったが, いずれの条件でも圧粉密度にほとんど変 化が見られないことから, 本実験では一番処理温度 が低い1073K一定で還元を行なった.

成形圧力についても196MPaまで行なったが, 196M Pa以上では圧粉体に割れが発生するケースもあった ため, 圧粉密度も考慮し本実験では147MPa一定で行 なった.

Fig. 3 は還元処理の効果を検討するために行なっ た研削首, 還元首および加炭首の圧粉体での示差熱 分析(DTA)結果を示す. 研削首は1141Kより吸熱反応 が始まり1213K付近で極小值をとつた. 還元首と加炭 首は研削屏よりやや高い 1123K付近から吸熱反応が 始まり $1173 \mathrm{~K}$ 付近で研削首と比較してかなり小さな 吸熱ピークをとっている.これらの傾向を考察する と, 研削首は酸化物を多く含み, それら酸化物が還 元されることによりDTAで吸熱反応が大きく現われ, 逆に酸化物が既に還元されている還元および加炭屑 は比較的小さいピークとなったと考えられた.

次に、これら圧粉体の酸素 $\left(0_{2}\right)$ 量を測定するため $\mathrm{X}$ 線マイクロアナライザー(EPMA)による $0_{2}$ の X 線強

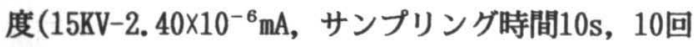
平均）の測定を行なった結果, 研削屑の $0_{2}$ 量は 1183 ～1433cps, 還元および加炭首は673 692 cpsの結果 が得られた.これより, 屑に含まれる $0_{2}$ 含有量が少
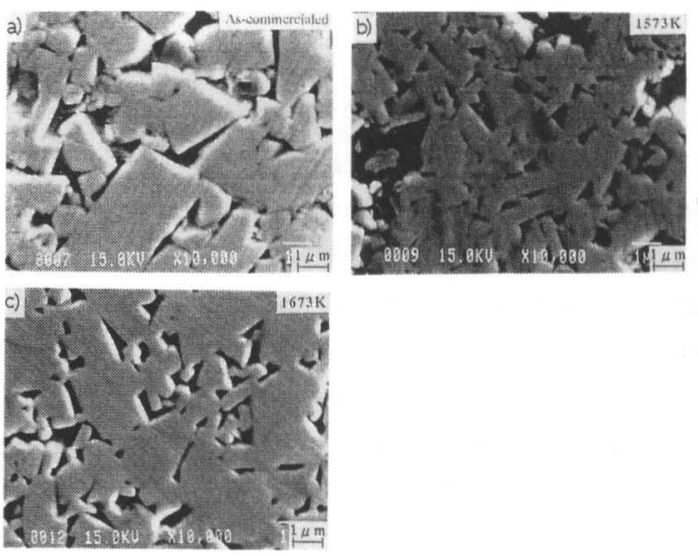

Photo. 1 SEM micropraphs of the sintered sample using by the grinded wastes.

なく, 強度比による半定量結果ではあるが研削㞕は 還元屑等に比較して約 2 倍の酸素が存在しているこ とが判明し, DTA結果ともよく対応した.

さらに, これら酸素の存在形態についてX線回折 で同定を試みたがW, Fe等の化合物としては存在せず 研削加工面表層のみの変化もしくはごく微量な量な ため化合物としては同定できなかった.

Photo. 1 は研削首をそのまま成形十焼結加工した 時のミクロ組織を示す. a)は市販G3超硬合金, b)は 研削屑を1573Kで, c)は1673Kでそれぞれ3.6Ks保持し 焼結したものである.b)の1573KではWCの粒径も小さ く黒く観察されるCo相の塊またはポアと思われる領 域が比較的大きく偏析している. 一方, c)の1673Kの 焼結条件ではWC粒の成長も確認され黒く観察される Co相の厚さもa)の市販G3焼結製品と比較しても大き な違いが認められなかった.

Table 2はPhoto.1で示した研削首および還元屑を 成形圧力 $147 \mathrm{MPa}$, 焼結温度 $1673 \mathrm{~K}$ (水素雾囲気妒) で 焼結した試料の物性値を示す. 硬度值は研削首(Non -reduced), 還元屑(Reduced)ともJIS規格と比較して ほほ同程度の硬度值が得られたが, 抗折力は研削首 でJIS規格值の48～71\%，息元屑ではさらに低下し 45 〜 55\%と大幅に下回る結果となった. 還元処理により

Table 2 Mechanical properties of the sintered sample obtained by 2 type wastes.

\begin{tabular}{|c|c|c|c|}
\hline & Non-reduced & Reduced & Reference JIS-G3 \\
\hline Hardness $\left(\mathrm{H}_{\mathrm{R}^{\mathrm{A}}} \mathbf{)}\right.$ & $87.5-88.5$ & $87.6-88.8$ & $>89$ \\
\hline $\begin{array}{l}\text { Transverse rupture } \\
\text { strength } \quad(\mathrm{MPa})\end{array}$ & $657 \sim 974$ & $619 \sim 754$ & $>1375$ \\
\hline
\end{tabular}


研削首の成形性は改善されたが, 抗折力は逆に劣化 し，抗折試験後の破面も脆性破面であった。

この原因として研削屏時でのC量の低下(Table 1) があげられるが，逼元屏では同様に元素分析を行な つた結果，Co量は研削屏と同含有量 (8.7mass\%)であ ったが，C量は研削屑よりさらに低い4.2〜4.3mass\% となっていた.このC量の減少は還元处理をおこな っていることから当然と考えられるが, 物性值に及 ほす影䇺についてX線回折により,WC-Coの化合形態 の変化について検討した。

Table 3は還元居まま,浐元屏の焼結加工後および 黒鉛添加による加炭屑の焼結加工後試験片の回折結 果である．研削屏を還元することによりWCと共にW6 $\mathrm{Co}_{6} \mathrm{C}$ と少量のク相 $\left(\mathrm{W}_{3} \mathrm{Co}_{3} \mathrm{C}\right)$ が同定された.さらにこ れを焼結することによりWCと ク相が確㒛された。こ れはC 量不足によりWCの他にW $\mathrm{W}_{2} \mathrm{C}$ 牲成し,さらにCo が化合することによりク相になることにより脆化す る. また, 結合相としてのCo相がWC界面で薄くなり , 抗折力に大きく影響する平均自由行路 (mean free path)が小さくなったため,これらの複合効果により 抗折力が大幅に低下したものと考えられる ${ }^{6)}$.この ため，影響を与えているCについて黒鉛唀加により

Table 3 Results of X-ray diffraction patterns of 3 treated reduced wastes.

\begin{tabular}{|c|c|c|}
\hline Reduced wasles & WC $\quad \mathrm{W}_{6} \mathrm{Co}_{6} \mathrm{C} \quad\left(\mathrm{W}_{3} \mathrm{CO}_{3} \mathrm{C}\right)$ \\
\hline $\begin{array}{c}\text { Reduced specimen } \\
\text { (Sintered) }\end{array}$ & WC $\quad \mathrm{W}_{3} \mathrm{Co}_{3} \mathrm{C}$ \\
\hline $\begin{array}{c}\text { Reduced+6\%C added } \\
\text { (Simered) }\end{array}$ & WC \\
\hline
\end{tabular}

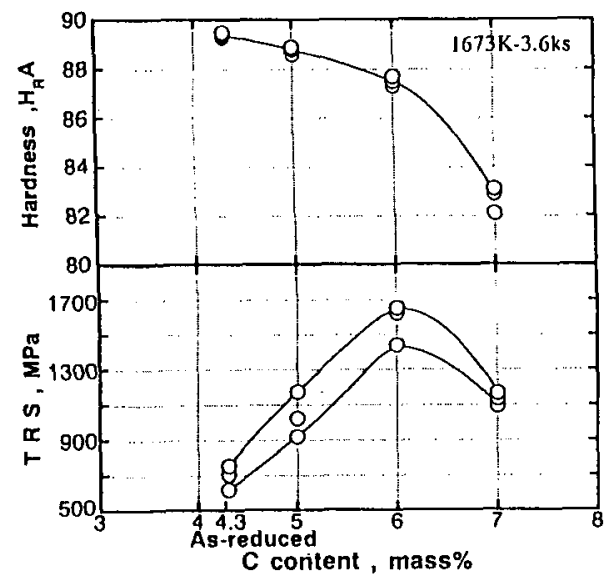

Fig. 4 Effect of carbon content on the mechanical properties by reduced wastes.

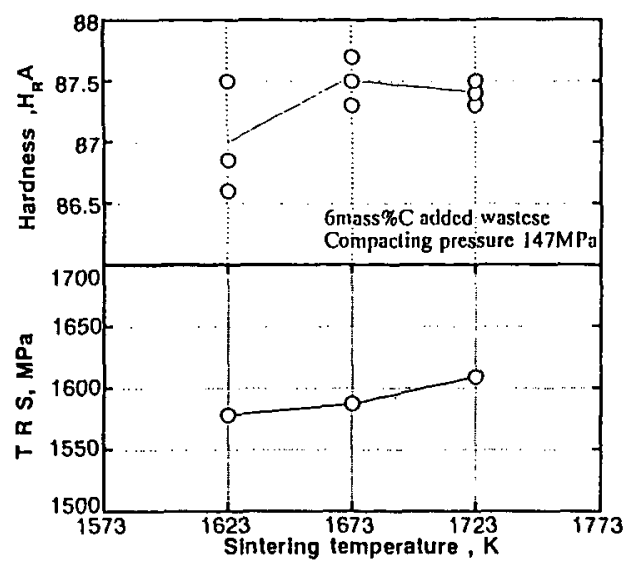

Fig. 5 Relation between the sintering temperature and the mechanical properties by the recarburized wastes (6mass\% $\mathrm{C}$ added).

加炭してさらに抗折力の改善について検討した.

Fig. 4 は加炭量と硬度値および抗折力の関係につ いて示している. なお，加炭量は使用した還元屏の C量が4.3mass\%あり，それに加えた黒鈶の量との緼 量で表示した. 硬度值はC量が增加するにつれて低 下しているが, 抗折力はC量 6mass\%の時1375MPa以 上のJIS規格を上回る再生超硬合金が得られた.その 際の化合物は Table 3に示すようにWCのみが得られ ，市販材料と同様の結果となった. 7mass\%Cでは抗 折力が低下するが，この原因としてWCとCo相以外に 過剩添加となった黒鉛が，結晶粒界に遊離黒鉛4) と して存在していた.

Fig. 5 は抗折力の最大值が得られた6mass\%Cにお ける硬度值と抗折力に及ほす焼結温度の影響を示す .硬度值では1623Kの焼結温度でいくぶん低下するが 0.5 程度と大差ない。一方, 抗折力では楛結温度の上 昇に伴い抗折力も若干ではあるが上昇している。

Photo. 2 は同様に焼結温度の相違によるミク口組 織を示す. 雨物性值の低い a)の1623KではCo相の扁 析が諗められるが, b)の1673K以上の焼結温度ではWC 粒とCo相間がよい対応を示しており、Fig.5の物性值 も考慮し，工業的に考えると焼結温度は1673Kで允分 であると思われた。

Fig. 6 に本実験で得られた研削屏の再生加工工程 のフローチャートを示す，塊状の研削屏を种水等で 㩇汼洗浄し，屑の酸化を防ぐため343K-3.6Rsの条件 で真空翰燥を行ない,ふるいにより100mesh以下の屑 だけを回収する。次に，酸化物等の除去を目的とし た還元処理を水素䨌囲気妒を用いて 1073K-3.6Ks保 


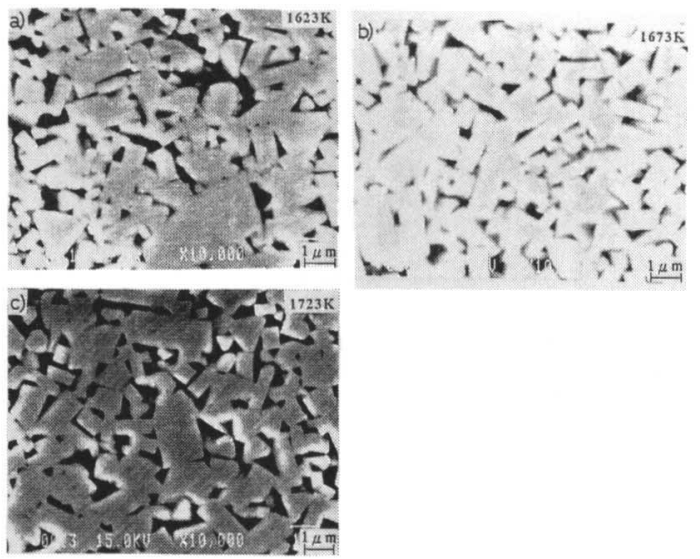

Photo. 2 SEM micrographs of recarburized sample (6mass\%C added) with various sintering temperature.

持の条件で行なう. そして, 研削加工および還元処 理でおこる脱炭によるC 量を調整するために黒鉛に よる加炭を行ない, トータルC 量6mass\%に調整する ・ここまでの工程で再生超硬合金の原料粉末は完成 する. その後圧縮圧力147MPaで成形し, 水素雲囲気 炉を用いて 1673K-3.6Ksの条件で焼結することによ り, 研削屑のリサイクルが可能であることが判明し た.

このリサイクル工程で得られた超硬合金の物性值 は硬度值 $\left(\mathrm{H}_{\mathrm{R}} \mathrm{A}\right)$ で87.0 88.0とJIS規格(89以上)に対 して1〜2低くなるが, 抗折力は1420～1650MPaと大幅 な改善が見られJIS規格(1375MPa以上)を充分クリア し, 試作金型等としての超硬合金の再利用の可能性 を見出すことができた。

\section{4 ま と め}

研削屏を利用して超硬合金を再生する際, 可能な 限り経済的な工程で再生するために各工程での諸因 子が焼結製品の物性値に与える影響について検討し た結果, 以下の結論を得た。

1. 研削屑の化学組成は市販焼結製品と比べ, 研削 加工によるC の低下および研削盤等からのFe等の 不純物を含んでおり, これら屑の一部は酸化物を 形成していた. また, 粒径も $44 \mu \mathrm{m}$ 以上の屑が約 38 \%も存在しばらつきがあった.このため,成形が非 常に困難であり, かつ焼結体の物性值も低く, 研 削屏から直接の再生は不可能であった。

2. 研削首を逼元処理することにより, 成形性が向 上し,圧分密度が研削屑のそれに比べて約1.5倍に なった. しかし焼結体の物性值は逼元処理により

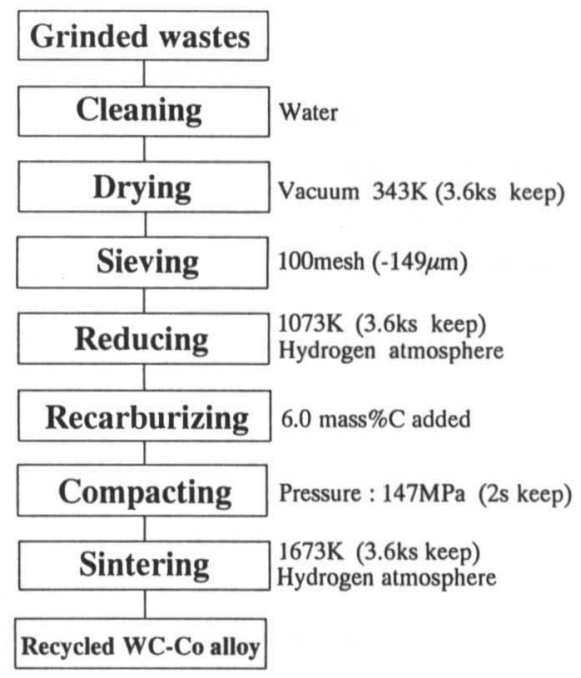

Fig. 6 Recycling process of hard metals obtained by the grinded wastes.

さらに脱炭が進み $\eta$ 相 $\left(\mathrm{W}_{3} \mathrm{Co}_{3} \mathrm{C}\right)$ が生成し,これが 脆化の原因となっていた.

3. 還元処理によるC 量の不足分を補うため黒鉛涹 加による加炭処理を行なった結果, トータル6mass \%Cに調整した屑を使用した焼結体がJIS規格の抗 折力を满足する結果が得られた。しかし, 硬度值 は若干低い結果となっていた.

4. 1073K-3.6Ksの条件で還元され, かつ絡炭素量6 mass\%に加炭した研削屑を使用し, 147MPaで成形し 1673K-3.6Ks の条件で水素雾囲気で焼結すること により, 再生された超硬合金の物性值はJIS規格を ほほ满足する値が得らた．これにより, 再生超硬 合金は 7 工程によりリサイクルが可能となった.

\section{謝辞}

本研究を遂行するにあたり, 終始実験に協力され た岩手大学工学部学生和田光正君 (現: 青森フジク ラ侏）に対し，心から感謝の意を表します。

\section{文献}

1)原田 : 資源リサイクル, 資源・素材学会綟(1988)

2)浜田, 佐藤 : 資源・素材学会誌, 107(1991) 109.

3)山内 : 資源処理技術, 36(1989) 14.

4)吉田 : 超硬工具, 日刊工業新聞社(1982) 12.

5)庄司, 永井, 秋山 : 粉末冶金㯕論, 共立出版(1984) 30.

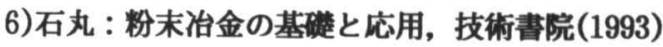
140 . 